Fixed Point Theory, 18(2017), No. 2, 625-640

DOI 10.24193/fpt-ro.2017.2.50

http://www.math.ubbcluj.ro/ nodeacj/sfptcj.html

\title{
SOME FIXED POINT RESULTS FOR A NEW THREE STEPS ITERATION PROCESS IN BANACH SPACES
}

\author{
VATAN KARAKAYA*, YUNUS ATALAN**, KADRI DOGAN*** \\ AND NOUR EL HOUDA BOUZARA**** \\ *Department of Mathematical Engineering, Yildiz Technical University \\ Davutpasa Campus, Esenler, 34210 Istanbul, Turkey \\ E-mail: vkkaya@yahoo.com, dogankadri@hotmail.com \\ **Department of Mathematics, Yildiz Technical University \\ Davutpasa Campus, Esenler, 34220 Istanbul, Turkey \\ E-mail: yunus_atalan@hotmail.com,bzr.nour@gmail.com \\ *** Department of Mathematics and Science Education, Artvin Coruh University, City Campus, \\ 08000 Artvin,Turkey \\ **** Mathematical Faculty, University of Science and Technology, Houari Boumedine, Bab-Ezzouar, \\ 16111, Algies, Algeria.
}

\begin{abstract}
In this paper, we introduce a three step iteration method and show that this method can be used to approximate fixed point of weak contraction mappings. Furthermore, we prove that this iteration method is equivalent to Mann iterative scheme and converges faster than Picard-S iterative scheme for the class of weak contraction mappings. We also present tables and three graphics to support this result. Finally, we prove a data dependence result for weak contraction mappings using this three step iterative scheme.
\end{abstract}

Key Words and Phrases: A new iterative scheme, strong convergence, weak contraction mapping. 2010 Mathematics Subject Classification: 47H10, 47H09.

\section{REFERENCES}

[1] M. Abbas, T.Nazir, A new faster iteration process applied to constrained minimization and feasibility problems, Matematicki Vesnik, 66(2014), 223.

[2] R.P. Agarwal, D. O'Regan, D.R. Sahu, Iterative construction of fixed points of nearly asymptotically nonexpansive mappings, J. Nonlinear Convex Anal., 8(2007), 61.

[3] V. Berinde, Iterative Approximation of Fixed Points, Springer, Berlin, 2007.

[4] V. Berinde, On the approximation of fixed points of weak contractive mappings, Carpathian J. Math., 19(2003), 7-22.

[5] R. Chugh, V. Kumar, S. Kumar, Strong Convergence of a New Three Step Iterative Scheme in Banach Spaces, Amer. J. Computational Math., 2(2012), 345-357.

[6] K. Dogan, V. Karakaya, On the convergence and stability results for a new general iterative process, The Scientific World J., 2014(2014), 8 pages.

[7] F. Gürsoy, V. Karakaya, B.E. Rhoades, Data dependence results of new multi-step and Siterative schemes for contractive-like operators, Fixed Point Theory Appl., 2013(2013). 
[8] F. Gürsoy, V. Karakaya, A Picard-S hybrid type iteration method for solving a differential equation with retarded argument, arXiv preprint arXiv:1403.2546, (2014).

[9] S. Ishikawa, Fixed Point By a New Iteration Method, Proc. Amer. Math. Soc., 44(1974), 147150.

[10] I. Karahan, M. Özdemir, A general iterative method for approximation of fixed points and their applications, Advances in Fixed Point Theory, 3(2013), 510-526.

[11] V. Karakaya, K. Doğan, F. Gürsoy, M. Ertürk, Fixed Point of a New Three-Step Iteration Algorithm under Contractive-Like Operators over Normed Spaces, Abstract Appl. Anal., 2013(2013), 9 pages.

[12] W.R. Mann, Mean Value Methods in Iteration, Proc. Amer. Math. Soc., 4(1953), 506-510.

[13] M.A. Noor, New Approximation Schemes for General Variational Inequalities, J. Math. Anal. Appl., 251(2000), 217-229.

[14] M.O. Osilike, Stability results for the Ishikawa fixed point iteration procedure, Indian J. Pure Appl. Math., 26(1995), 937-945.

[15] W. Pheungrattana, S. Suantai, On the Rate of Convergence of Mann, Ishikawa, Noor and SP Iterations for Continuous on an Arbitrary Interval, J. Comput. Appl. Math., 235(2011), 3006-3914.

[16] E. Picard, Memoire sur la theorie des equations aux derivees partielles et la methode des approximations successives, J. Math. Pures Appl., 6(1890), 145-210.

[17] S.H. Khan, A Picard-Mann hybrid iterative process, Fixed Point Theory Appl., 1(2013), 1-10.

[18] S.M. Şoltuz, T. Grosan, Data dependence for Ishikawa iteration when dealing with contractive like operators, Fixed Point Theory Appl., 2008(2008), 7 pages.

[19] X. Weng, Fixed point iteration for local strictly pseudocontractive mapping, Proc. Amer. Math. Soc., 113(1991), 727-731.

Received: March 6, 2015; Accepted: October 30, 2015. 